\title{
Signaling Pathway
}

National Cancer Institute

\section{Source}

National Cancer Institute. Signaling Pathway. NCI Thesaurus. Code C17132.

An elaboration of the known or inferred interactions involved in a signal transduction

pathway. 